\title{
DESIGNING ONLINE SUPPORT GUIDES FOR LIBRARIANS MANAGING STEM MAKER ACTIVITIES
}

\section{Aubrey Rogowski, ${ }^{*}$ Mimi Recker, \& Victor R. Lee}

Department of Instructional Technology and Learning Sciences, Utah State University, Logan, Utah

*Address all correspondence to: Aubrey Rogowski, Department of Instructional Technology and Learning Sciences, Utah State University, 2830 Old Main Hill, Logan, UT 84322-2830; Tel.: (+1) 435-797-2694, E-mail: aubrey.rogowski@aggiemail.usu.edu

\begin{abstract}
Libraries are increasingly offering activities and programs that engage youth in science, technology, engineering, and math-rich "Making." However, many librarians do not have access to necessary training, resources, or relevant content knowledge to help implement these kinds of Maker programs. This article describes a design-based research project in which we first engaged in sustained contextual inquiry to better understand the work practices of school and public librarians in small town and rural libraries and their perceptions of implementing Maker activities. Findings informed the design of online instructional guides to help librarians learn to implement informal beginner-level Maker programming and activities for youth. We describe three genres of online instructional guides and the design guidelines that inform them. We also describe our process for testing online guide utility and usability.
\end{abstract}

KEY WORDS: online instructional guides, open access, Making, STEM, libraries, librarians

\section{INTRODUCTION}

Libraries are increasingly expanding and modifying their spaces and services to better accommodate collaboration and learning. One growing area in this transformation is the provision of programs and activities that engage youth in science, technology, engineering, and math (STEM)-“Maker" activities and programming (Martin, 2015; Subramaniam et al., 2014). Maker activities can support youth in pursuing their interests by creating artifacts 
that blend digital and physical technologies, tinkering with robotics, or coding in environments such as Scratch (Lee et al., 2018b; Sheridan et al., 2014).

In response, many librarians are taking on greater leadership and technology roles to support these new Maker-related activities (Preddy, 2013; Sands et al., 2018). These roles may extend beyond what was provided by their previous education or experience. Moreover, access to necessary training or resources to implement these kinds of programs is often lacking (Remold et al., 2016). This is especially true for librarians working in small-town or rural libraries.

In this article, we describe a multiyear project in which we first engaged in sustained contextual inquiry to better understand the work practices of small-town and rural school and public librarians. We also sought to understand their perceptions in implementing STEM-rich Maker activities, resources that librarians used to facilitating these activities, and challenges that were encountered (Lee et al., 2017).

Our analyses revealed several constraints and affordances within the librarians' work contexts. First, youth patrons typically attended library programs on an inconsistent and drop-in basis. This meant that library Maker activities needed to support a range of skills, commitments, and experiences. Second, the librarians and youth voiced strong preferences for library programs that were informal in nature, not strongly prescriptive or classroom-like, and connected to a variety of youth interests (Lee et al., 2018a). Third, librarians expressed concerns about facilitating a program in which they often lacked deep-content expertise. Fourth, librarians typically supported many kinds of activities and programs. For example, some librarians only offered "leave it on the table" activities for youth during free time (that we call passive programming), whereas others scheduled structured youth activities on a regular basis. Finally, it was imperative that activities be low cost and did not require extensive use of high-end computers, because many small libraries lack such resources.

Through our interviews with librarians, we also found that they often turned to the Internet for information on how to plan Maker programs. However, the librarians noted that discovered resources were often inappropriate or unrealistic for library settings. For example, some resources feature expensive equipment (e.g., three-dimensional printers) and others required extensive technological or coding knowledge. Instead, the librarians wanted practical models that showed realistic images of Maker activities that could unfold in their libraries in attainable and affordable ways.

On the basis of our study of librarian contexts and our resulting knowledge of the nature of their work practices, we then iteratively designed, developed, and tested a suite of online instructional guides. These were intended to help library personnel, who were assigned to teen programming, to implement informal Maker activities. In the section below, we 
provide examples of the kinds of STEM-rich Maker activities that we supported. We then describe three genres of online instructional guides to support librarian learning and the design guidelines informing them.

\section{MAKER ACTIVITIES}

In collaboration with several rural librarians in the Rocky Mountain region, we began by selecting several STEM-rich Maker activities that not only fit the constraints identified above, but were also feasible for their library, affordable, and aligned with their vision for their spaces. Example of Maker activities included

- Makey Makey, a digital tool that can turn everyday conductive objects (e.g., spoons, bananas) into touch pads or keyboard controllers to use with computer games and programs (Resnick and Rosenbaum, 2013)

- Squishy Circuits, built using Play-Doh, light-emitting diode (LED) lights, and a battery to create a basic electrical circuit (Johnson and Thomas, 2010)

- K'Nex Kits, enabling exploration of engineering concepts by constructing small models of roller coasters, Ferris wheels, etc.

- Paper circuits, using copper tape, colored LED lights, and coin cell batteries to embed circuits in variety of light-up paper creations, for example, light-up greeting cards and Star Wars lightsabers (Lee and Recker, 2018; Peppler 2013; Shorter et al., 2014).

\section{GENRES OF ONLINE INSTRUCTIONAL GUIDES}

To support librarians in learning about STEM-rich Making activities, we designed three genres of online instruction options: (1) program guides, (2) tips and tricks guides, and (3) how-to video tutorials. For each Maker activity, we developed a program guide, unless a wealth of educator guide information was already available online. In this case, a tips and tricks program guide helped direct librarians to available resources that were just applicable to a library setting, along with pictorial examples of library implementations (because most educator support materials assume classroom settings).

Our how-to video tutorials helped convey basic concepts surrounding a specific Maker activity. The videos could also be shown to youth, to serve as another form of instructional support. To date, we have developed how-to video tutorials for e-textiles and paper circuits. These videos are short-less than 3 min long-and demonstrate the basics for a librarian or youth to quickly get started on their own project. 


\title{
4. DESIGN GUIDELINES
}

We distilled four design guidelines that informed development of online instructional resources.

\subsection{Educative Instructional Guides}

We designed our guides to be educative, in that we drew from research on the design of kindergarten-12 curriculum materials that are intended to help teachers learn to effectively adopt and adapt materials to their specific instructional context (Ball and Cohen, 1996; Davis and Krajcik, 2005; Davis et al., 2017; Schneider and Krajcik, 2002). Curriculum materials are intended to act as resources for supporting student learning, but they are also increasingly seen as tools to help educators learn to engage in teaching practices that may be new to them. Educative supports can come in a variety of forms, ranging from supportive websites, to specific annotations in instruction, to forms of layout and visual displays that provide consistent and clear support of best practices.

Because librarians differ in levels of subject matter knowledge, instructional guides were designed to convey "big ideas" behind the Maker activity, with multiple forms of highlighting and representation of subject-matter knowledge. These were summarized with pithy sayings (or "slogans") that were associated with the various Maker activities, such as "close the loop" and "beware of tears" (see Fig. 1). In addition, guides conveyed essential steps for getting started by providing a do-it-yourself guide for youth to follow. For example, Fig. 2 shows the use of a paper circuit template with concise step-by-step instructions to complete a simple electronic circuit. Excluded was some technical information, such as how electron flow is the basis of electricity or how conductive thread has limits because of the way in which metal is integrated into thread fibers.

\section{Close the loop! \\ Circuits have to eventually connect positive and negative ends of a battery.}

\section{Beware of Tears!}

\author{
Tears in copper tape break the circuit. To \\ repair, overlap a lot of copper tape firmly \\ over the tear.
}

FIG. 1: Slogans for paper circuit Maker program 


\section{How to Make a Paper Circuit}

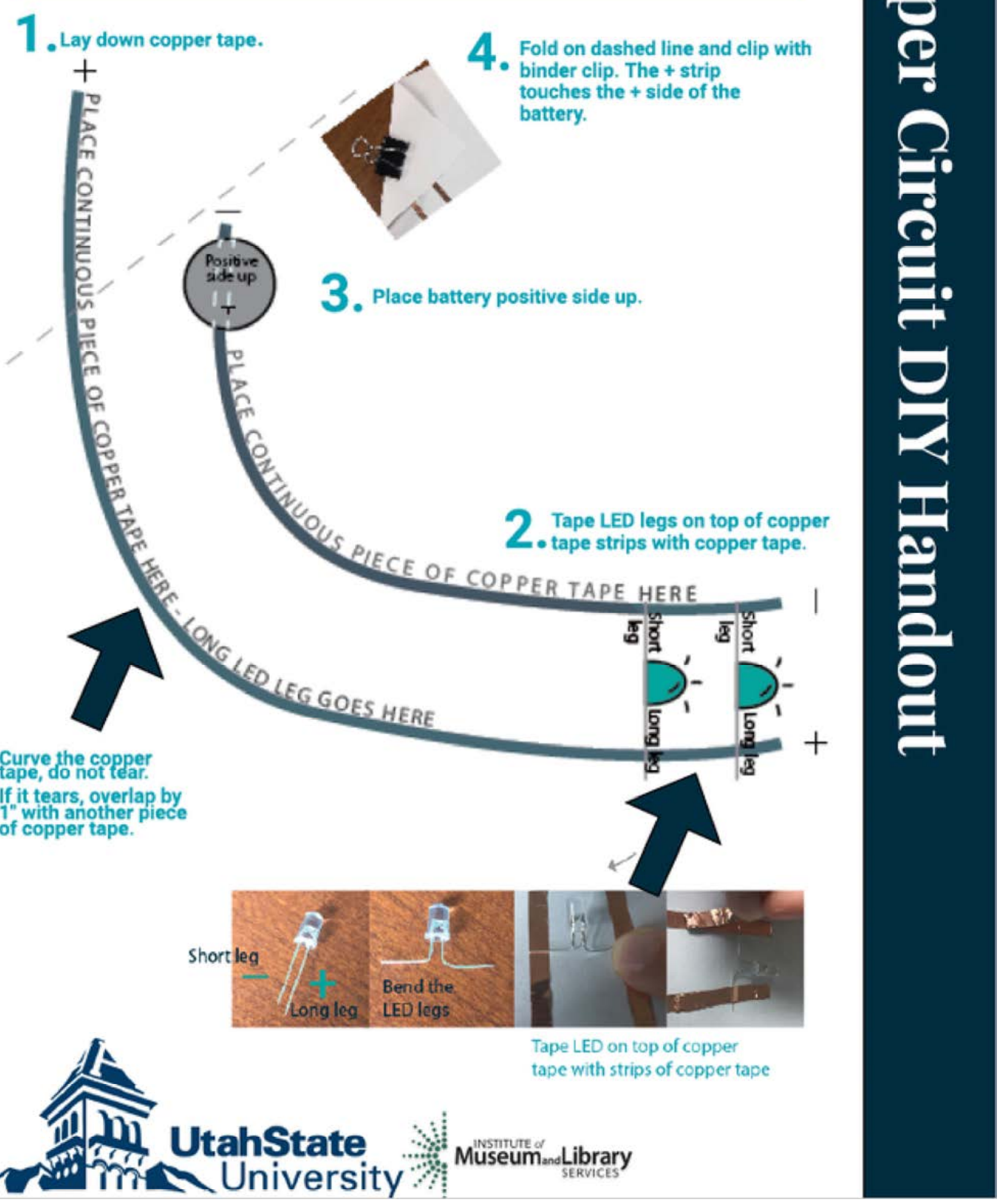

FIG. 2: Paper circuit do-it-yourself (DIY) guide for youth 


\subsection{Extensive Use of Visual Representations}

Our findings showed that librarians typically prefer instructional materials that could be quickly appraised at a glance (Phillips et al., 2018). They also prefer pictorial examples that showed realistic images of library Maker activities and conveyed a sense of possibility. This was the direct feedback that we received from practicing librarians. We thus designed guides to incorporate these features, and librarians could then customized these examples to specific interests of their participating youth.

\subsection{Adaptable Sequence and Structure}

To accommodate the different types of library program styles, guides displayed clear, recurring routines that could be used in both librarian-led and passive programs. Figure 3 shows example guides for both types of programs. Online instructional guides also suggested a simple activity structure, consisting of "learn, make, share" sequences for Maker activities (see Fig. 3). To help convey this structure, the guides included simplified templates and tips so that youth and librarians could quickly get started on projects.

\subsection{Support for a Range of Librarian Maker Practices}

Librarians often design their own programing by adapting already-established programs to fit the needs of their youth and library. Features were included in the instructional guides to show images of various Maker practices and provide links to available resources to support customized implementations of Maker programming (see Fig. 4).

In addition to the information available in the instructional guides, we curated lists of online resources on our website to further support librarians in customizing programs. For example, we put together shopping lists of supplies required for each instructional guide, with links to best prices. We also included links to other websites and books that were related to various Maker topics if librarians wished to add those to their library collections. 


\section{Leave it on the Table:}
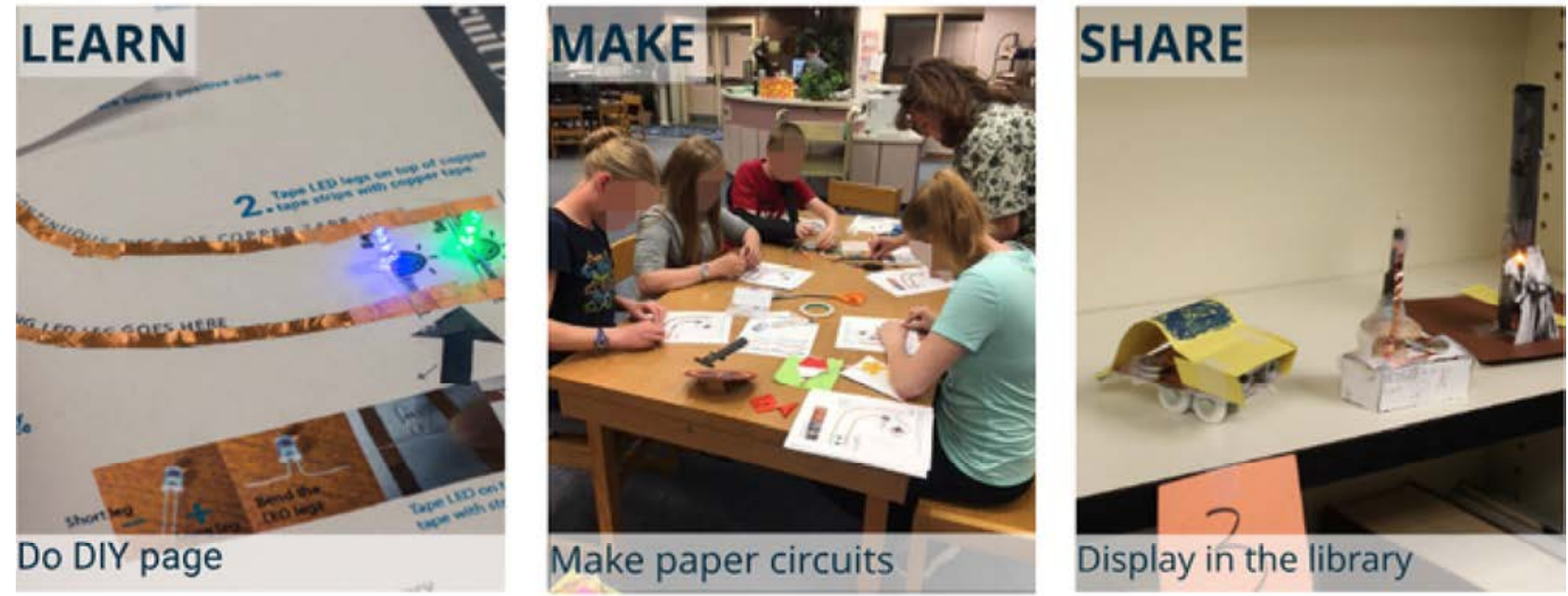

\section{Librarian - Run Activity:}
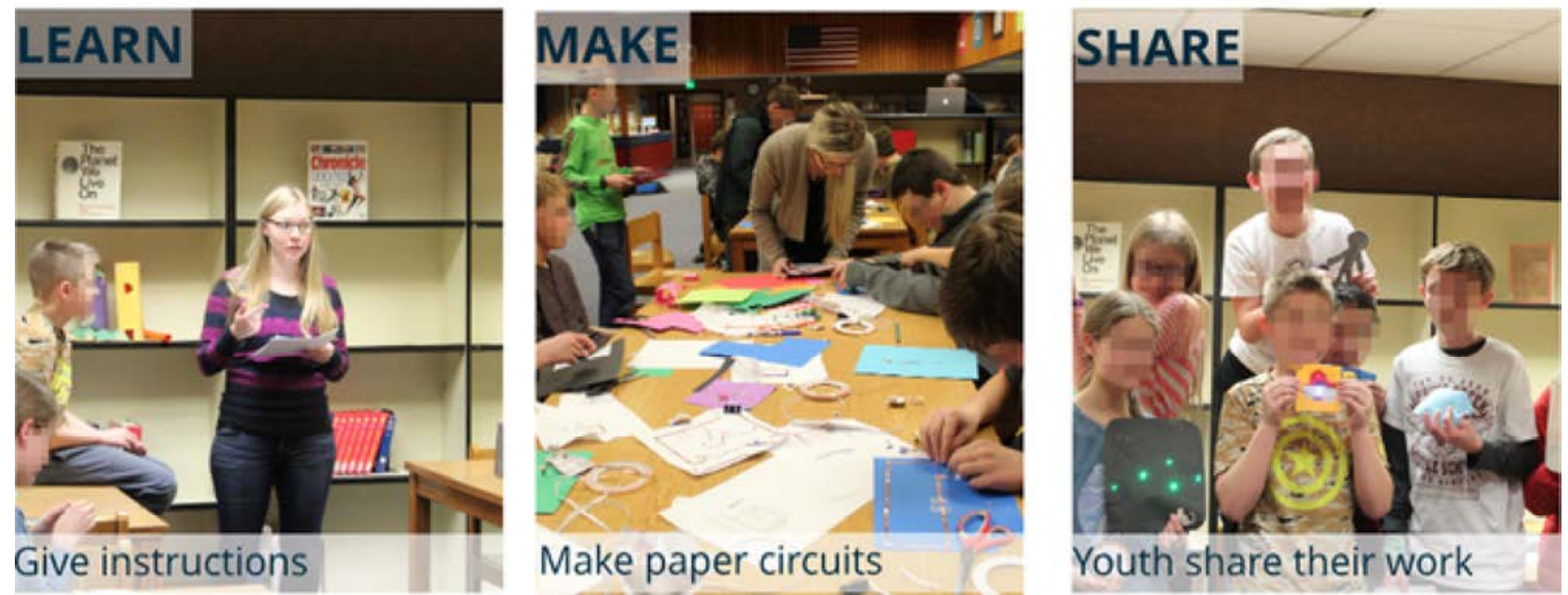

FIG. 3: Leave it on the table, librarian-run activity examples, and "learn, make, share" model. DIY, Do it yourself 


\section{Resources:}

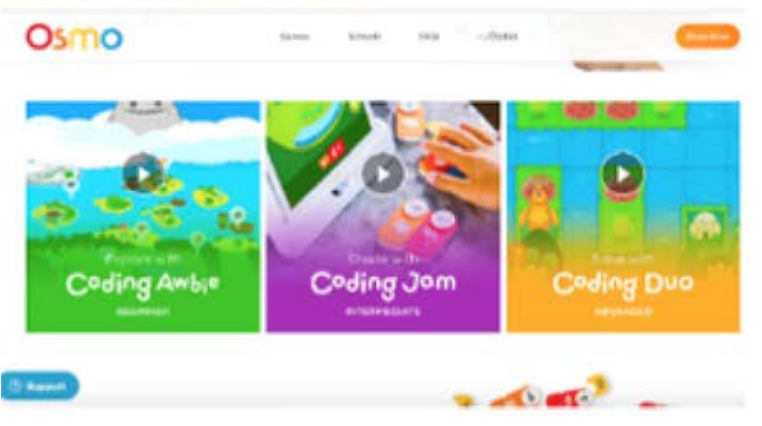

Osmo Coding Family

https://www.playosme.com/en/coding-family/

田
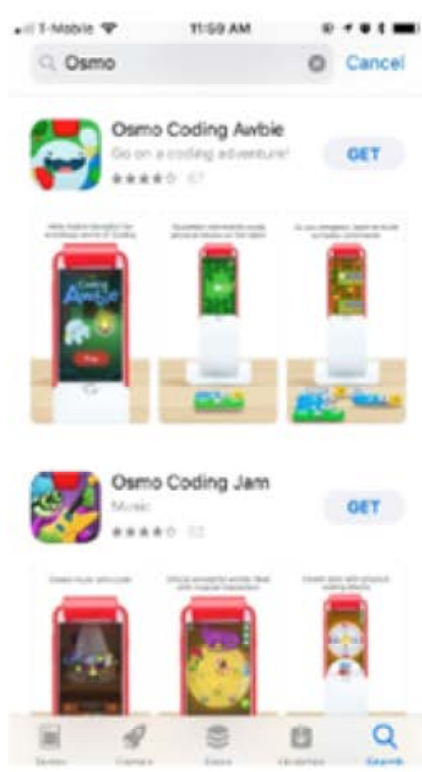

Apple App Store

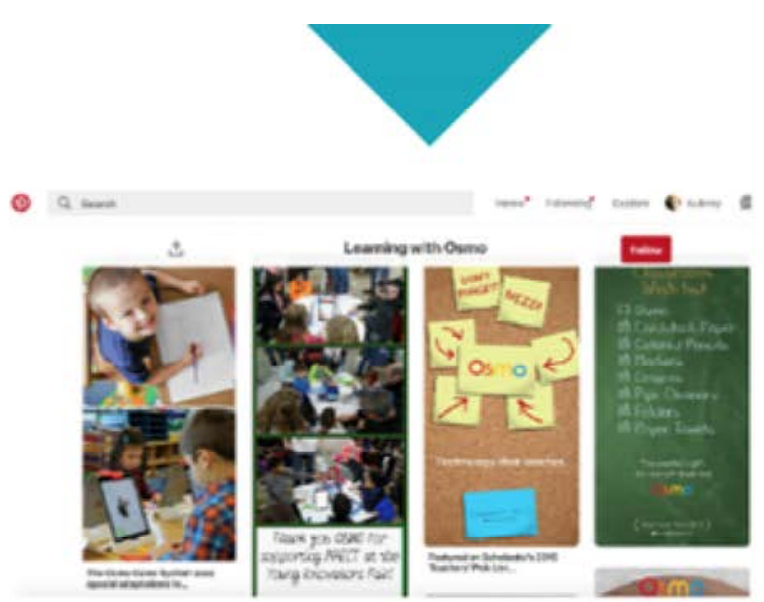

Learning with Osmo Pinterest Board https://pin.it/p32c5eznkppeag

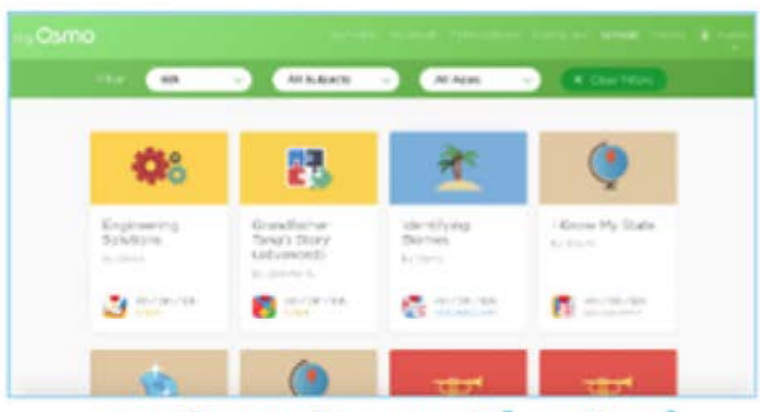

myOsmo Lesson Plan Bank

https://my.playosmo.com

\section{Cautions:}

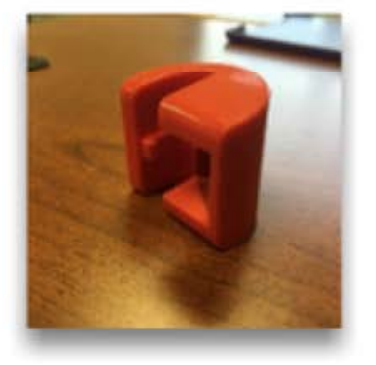

The red mirror piece likes to walk off. Some librarians have found it helpful to duck tape the piece to the iPad.

FIG. 4: Various resources included in a tips and tricks instructional guide for the Osmo, an interactive augmented reality digital tool for the iPad that converts the user-facing camera into an instrument for detecting action that takes place on a surface in front of the iPad (see playosmo.com for more information)

\section{DESIGN-BASED DEVELOPMENT}

Once we had initial designs, we began iterative cycles of design-based research (DesignBased Research Collective, 2003) to test, revise, and refine the online instructional guides. 
In the first phase, guide usability and usefulness were examined by conducting user testing with small groups of school and public librarians in rural communities. Librarians used a structured form to provide feedback (see Fig. 5). Most feedback addressed ways to improve quality and utility of guide images.

\section{Squishy Circuits Feedback Form}

\begin{tabular}{|c|c|c|c|c|}
\hline What I like..... & This is confusing... & $\begin{array}{l}\text { I feel like____ is } \\
\text { missing... }\end{array}$ & $\begin{array}{l}\text { I wish I'd known } \\
\text { before.... }\end{array}$ & I learned... \\
\hline $\begin{array}{l}\text { The simple } \\
\text { and easy to follow } \\
\text { directions }\end{array}$ & & $\begin{array}{l}\text { Positive and } \\
\text { negative signs } \\
\text { should be } \\
\text { bigger or } \\
\text { clearer. }\end{array}$ & $\begin{array}{l}\text { I am glad } \\
\text { I knew that } \\
\text { the short leg was } \\
\text { negative and the } \\
\text { Long was positive }\end{array}$ & $\begin{array}{l}\text { That playdough } \\
\text { is a conductor. }\end{array}$ \\
\hline
\end{tabular}

1. Is the program guide easy to understand and follow? yes

2. Is enough information given that you would be comfortable creating your own activity in your library space? ges - but include picture of light legs being positive and negative. 3. Other comments or suggestions

FIG. 5: Librarian feedback form, with responses

The second phase involved observations and interviews of rural librarians during use of the online instructional guides to implement a youth Maker program in their library. We found that participating librarians' enactments closely resembled the pictorial examples of implementation found in the guides, but opportunities for improvement of the guides arose. On the basis of these implementations, we again made revisions to the instructional guides. For example, we added a troubleshooting section to help librarians debug malfunctioning paper circuits (see Fig. 6). 

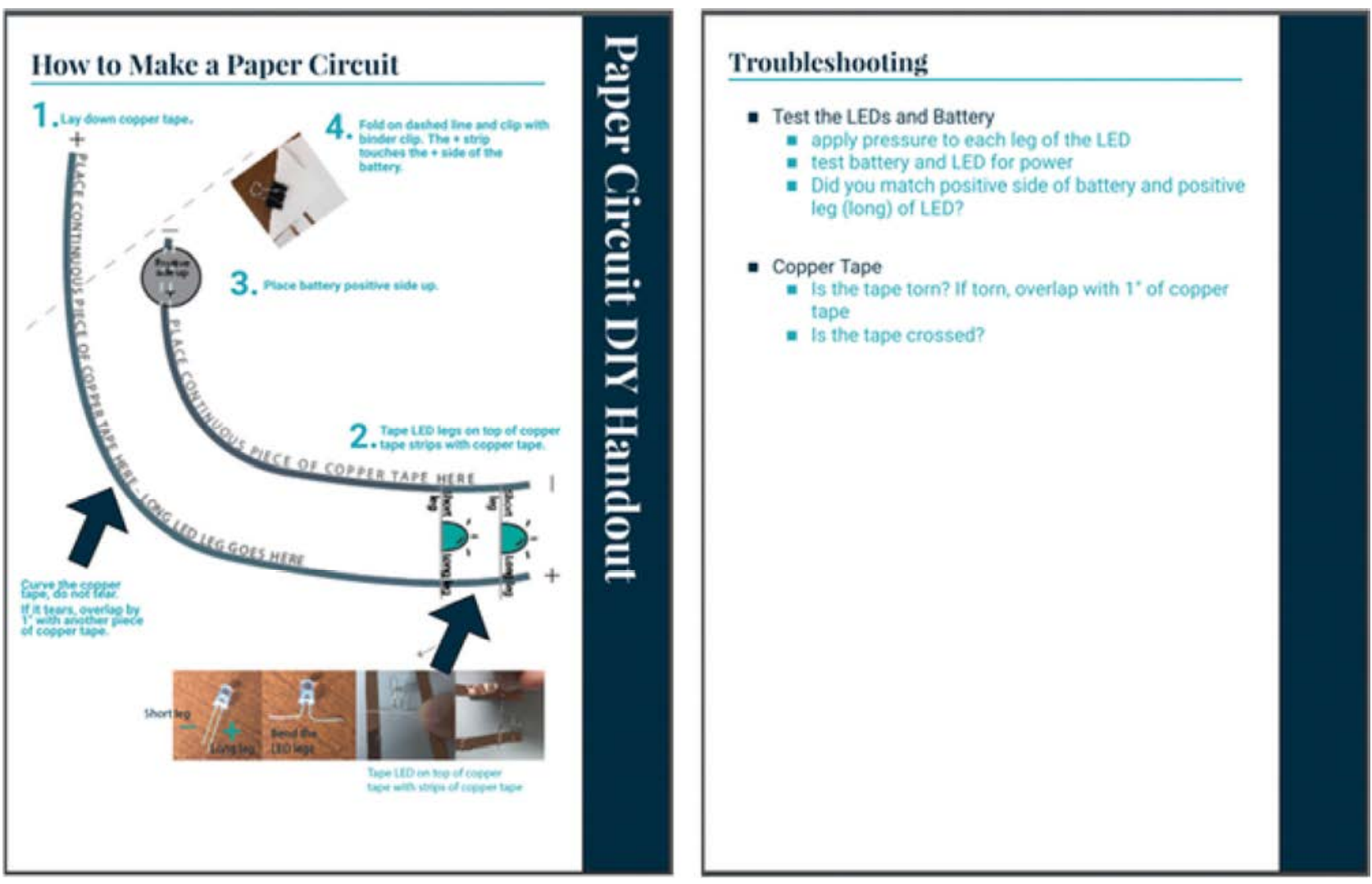

FIG. 6: Troubleshooting tips added to paper circuit instructional guide

\section{CONCLUSION}

This article describes our processes and design guidelines for developing and testing a suite of online instructional guides that are designed to support small-town and rural libraries that are learning to implement STEM-rich youth Maker activities. The guides and their accompanying resources are openly and freely available on library-making.usu.edu. Informally, we have seen a positive response to the guides being made available. Librarians have told us that they fill a niche that would otherwise have to be filled with even more of their own research. We envision the guides also being used in library preservice courses as resources for design of sample programs or models that librarians can use to create and share in future professional networks.

As libraries continue to evolve from a place of book collections to spaces and services supporting active learning, librarians too must learn to support a wider range of activities, including Maker activities. Because librarians, in general, have little formal STEM training and limited, if any, prior experience in facilitating Maker programs, resources are needed to support the learning of these new skills. Providing at-a-glance and tips and tricks instructional guides, how-to tutorial videos, and curated resources that are available online 
and in open-access formats can help to increase librarian confidence and ability to lead these types of Maker programs for youth. We believe that the processes described and the distilled guidelines can also be useful for others who may be developing supports for librarian learning.

\section{ACKNOWLEDGMENTS}

This material is based on work supported by the Institute of Museum and Library Services (RE-31-16-0013-16). Any opinions, findings, and conclusions or recommendations expressed in this material are those of the authors and do not necessarily reflect the views of the agency. We thank participating librarians and youth patrons.

\section{REFERENCES}

Ball, D.L. and Cohen, D.K. (1996), Reform by the Book: What Is_or Might Be-the Role of Curriculum Materials in Teacher Learning and Instructional Reform?, Ed. Res., vol. 25, no. 9, pp. 6-14.

Davis, E.A. and Krajcik, J.S. (2005), Designing Educative Curriculum Materials to Promote Teacher Learning, Ed. Res., vol. 34, no. 3, pp. 3-14.

Davis, E.A., Palincsar, A.S., Smith, P.S., Arias, A.M., and Kademian, S.M. (2017), Educative Curriculum Materials: Uptake, Impact, and Implications for Research and Design, Ed. Res., vol. 46, no. 6, pp. 293-304.

Design-Based Research Collective (2003), Design-Based Research: An Emerging Paradigm for Educational Inquiry, Ed. Res., vol. 32, no. 1, pp. 5-8.

Johnson, S. and Thomas, A.P. (2010), Squishy Circuits: A Tangible Medium for Electronics Education, Proc. of Conf. Hum. Fact. Comp. Syst., pp. 4099-4104.

Lee, V.R., Lewis, W., Searle, K.A., Recker, M., Hansen, J., and Phillips, A.L. (2017), Supporting Interactive Youth Maker Programs in Public and School Libraries: Design Hypotheses and First Implementations, in IDC 2017, Proc. of 2017 ACM Conf. Interaction Design Children, pp. 310-315.

Lee, V.R. and Recker, M. (2018), Paper Circuits: A Tangible, Low Threshold, Low Cost Entry to Computational Thinking, TechTrends, vol. 62, no. 2, pp. 197-203.

Lee, V.R., Recker, M., and Phillips, A. (2018a), Conjecture Mapping the Library: Iterative Refinements toward Supporting Maker Learning Activities in Small Community Spaces, Proc. of Int. Conf. Learning Sciences (ICLS), International Society of the Learning Sciences.

Lee, V.R., Rogowski, A., Phillips, A., Recker, M. (2018b), Using a "Light Touch" to Support Middle School Libraries with Implementing STEM-Oriented Maker Activities, Annual AECT Conf., Kansas City, MO. 
Martin, C. (2015), Connected Learning, Libraries, and Bridging Youth Interest, J. Res. Young Adults Libraries, p. 6.

Peppler, K.A. (2103), STEAM-Powered Computing Education: Using E-Textiles to Integrate the Arts and STEM, Computer, vol. 46, no. 9, pp. 38-43.

Phillips, A.L., Lee, V.R., and Recker, M.M. (2018), Supporting School Librarian Learning: New Opportunities for Instructional Technology Collaboration with School Librarians, in Branch, R.M., Ed., Educational Media and Technology Yearbook, vol. 41, Berlin: Springer, pp. 53-60.

Preddy, L.B. (2013), School Library Makerspaces: Grades 6-12, ABC-CLIO.

Remold, J., Fusco, J., Anderson, K., and Leones, T. (2016), Communities for Maker Educators: A Study of the Communities and Resources that Connect Educators Engaged in Making, Menlo Park, CA: SRI International.

Resnick, M. and Rosenbaum, E. (2013), Designing for Tinkerability, in Honey, M. and Kanter, D., Eds., Design, Make, Play: Growing the Next Generation of STEM Innovators, Abingdon, UK: Routledge, pp. 163-181.

Sands, A.E., Toro, S., Devoe, T., Fuller, S., and Wolff-Eisenberg, C. (2018), Positioning Library and Information Science Graduate Programs for 21st Century Practice, Washington, D.C.: Institute of Museum and Library Sciences.

Schneider, R.M. and Krajcik, J. (2002), Supporting Science Teacher Learning: The Role of Educative Curriculum Materials, J. Sci. Teacher Ed., vol. 13, no. 3, pp. 221-245.

Sheridan, K., Halverson, E.R., Litts, B., Brahms, L., Jacobs-Priebe, L., and Owens, T. (2014), Comparative Case Study of Three Makerspaces, Harvard Ed. Rev., vol. 84, no. 4, pp. 505-532.

Shorter, M., Rogers, J., and McGhee, J. (2014), Enhancing Everyday Paper Interactions with Paper Circuits, Proc. of 2014 Conf. Design. Interact. Syst., pp. 39-42.

Subramaniam, M.M., Ahn, J., Fleischmann, K.R., and Druin, A. (2014), Reimagining the Role of School Libraries in STEM Education: Creating Hybrid Spaces for Exploration, Library Quarterly, vol. 82, no. 2, pp. 161-182. 